\title{
Enhancing the Growth and Yield of Green Gram through Efficient Inoculation of AM Fungi and Rhizobium
}

\author{
M. Gomathy ${ }^{1}$, L. Srimathi Priya ${ }^{2}$, K.G. Sabarinathan ${ }^{1}$ and K. Kumuda ${ }^{3}$ \\ ${ }^{1}$ Agricultural College and Research Institute, Killikulam, Vallanadu, India \\ ${ }^{2}$ Horticultural College and Research Institute for Women, Trichy, India \\ ${ }^{3}$ Agricultural College and Research Institute, Madurai, India \\ *Corresponding author
}

Keywords

AM fungi,

Rhizobium, Green gram

Article Info

Accepted:

15 December 2020

Available Online:

10 January 2021

\section{A B S T R A C T}

Dual inoculation of AM fungi and Rhizobium is much essential for the leguminous plants to attain its maximum yield. Green gram is one among the pulses and considered to be an important pulse crop being a potential source of protein. A study was undertaken to enhance the growth and yield of green gram through efficient inoculation of AM fungi and Rhizobium. Different formulations were tested to evaluate the suitable one for green gram. AM fungi were applied as seed treatment and soil application along with water soluble formulation as well carrier based Rhizobium. The results revealed that the treatment that received both the biofertilizers were proven to be the best performer when compared to other treatments. Water soluble formulation of Rhizobium performed better with the soil and seed application of AM fungi in plant biometric observations, number of nodules, production of phosphatase enzyme etc. Hence the improved formulation performed better and reported to increase the yield of green gram.

\section{Introduction}

The repeated use of chemical fertilizers makes the soil to be unworthy for cultivation of crops as it detoriates the microbial population. Soil can be turned to fertile by the usage of organic fertilizers. Among the organic fertilizers biofertilizers are one of the important components that make the soil healthy. Among the biofertilizers AM fungi is one of the important biofertilizer that form association with almost 80 percentage of plants (Harley and Harley, 1987). Its symbiotic association was well studied by several researchers (Rajasekaran and Nagarajan, 2004). AM fungi can uptake the 
nutrients with the help of long extending hyphae that assures the continuous supply of water and nutrients. Rhizobium is one another important biofertilizers recommended to legumes. Legumes are cultivated through out India and its symbiotic nitrogen fixing partner is Rhizobium which fixes nitrogen in nodules. Mycorrhizal infection and Rhizobium nodulation in legumes plays a vital role for enhancing the growth and yield as both the partners supply nutrients required by the crop (Arumugam et al., 2010). Athar et al. (2005) reported better nodulation and nitrogen fixation in legumes due to the phosphorus nutrition. Nitrogenase activity was enhanced due to the application of AM fungi was reported by Kobae (2019). By keeping the above points the present study was undertaken to evaluate the efficiency of tripartite association.

\section{Materials and Methods}

Pot culture studies were carried out in the department of Soil Science and Agricultural Chemistry, Agricultural College and Research Institute, Killikulam with the following treatments with four replications

\begin{tabular}{|l|l|}
\hline Treatment & \multicolumn{1}{|c|}{ Details } \\
\hline T1 & $\begin{array}{l}\text { AMF (Seed coating }+ \text { Soil } \\
\text { application) }\end{array}$ \\
\hline T2 & Carrier based Rhizobium \\
\hline T3 & $\begin{array}{l}\text { Water soluble formulation of } \\
\text { Rhizobium }\end{array}$ \\
\hline T4 & T1+ T2 \\
\hline T5 & T1+ T3 \\
\hline T6 & Control \\
\hline
\end{tabular}

\section{Estimation of AM fungal colonization in} roots

Inoculated and un-inoculated plant roots were washed thoroughly with water and cut into 1 $\mathrm{cm}$ segments, immersed in FAA solution (formaldehyde $5 \mathrm{ml}$ : glacial acetic acid $5 \mathrm{ml}$ : alcohol $90 \mathrm{ml}$ ). The root bits were immersed and bleached in 10 per cent potassium hydroxide. After autoclaving at $5 \mathrm{lbs}$ pressure for $10 \mathrm{~min}$, root bits were washed with water for 3-4 times. The root bits were, then immersed in 30 per cent hydrogen peroxide solution for 10-15 min. Excess alkali in the root bits were rinsed with water and acidified in 3 per cent hydrochloric acid for $5 \mathrm{~min}$ and the acid was decanted. The root bits were stained with 0.05 per cent tryphan blue solution (tryphan blue $0.5 \mathrm{~g}$, glycerol $500 \mathrm{ml}$, $\mathrm{HCl}$ (1 per cent) $50 \mathrm{ml}$ and distilled water 450 $\mathrm{ml}$ ) and boiled for about $10 \mathrm{~min}$. One hundred root segments per treatment were examined under stereozoom binocular microscope at 10x for the presence of arbuscules, vesicles, external mycelium and spores (Phillips and Hayman, 1970).

AM colonization per cent $=$

Number of root bits with AM infection x 100

Total number of root bits examined

Estimation of AM fungal spores in rhizosphere soil

AM fungal spores were estimated from rhizosphere soil by wet sieving and decanting technique (Gerdemann and Nicolson, 1963). Rhizosphere soil samples (100 g) were taken in one litre beaker and water was added and stirred well and kept undisturbed for a few seconds. The aqueous portion was passed into four sets of sieves of 180, 106, $45 \mu \mathrm{m}$ size. Each sieving was collected into a small separate beaker.

\section{Sucrose centrifugation}

The residue from each sieving was collected and transferred to $50 \mathrm{ml}$ centrifuge tubes and centrifuged for 4 to $5 \mathrm{~min}$ at $1700 \mathrm{rpm}$ and the 
supernatant liquid was decanted. The pellets were resuspended in a sucrose solution (454 g sugar lit $^{-1}$ ), centrifuged again for $1 \mathrm{~min}$ and the supernatant was sieved and rinsed with water to remove the sugar. Supernatant was transferred into the counting dish and examined under stereo zoom binocular microscope. The spore number from each soil sample in duplicate was counted, tabulated and expressed as no per $100 \mathrm{ml}$ soil.

\section{Plant biometric observations}

Plant sample from each treatment was casually uprooted on 30 and 45 days after sowing (DAS) without damage to the root system and washed with tap water to remove the adhering soil particles. The growth parameters and other analyses were carried out.

\section{Shoot length}

At sampling periods, shoot length was taken from the ground level to the tip of the lengthiest shoot and expressed in $\mathrm{cm}$.

\section{Root length}

The root length of the plant was taken from the ground level to the tip of the lengthiest root and expressed in $\mathrm{cm}$.

\section{Acid and Alkaline phosphatase activity of roots}

\section{Acid phosphatase activity}

Ten gram of fresh mass of sample was ground thoroughly with acid washed sand in a pre chilled pestle and mortar with $20 \mathrm{ml} 0.2 \mathrm{M}$ acetate buffer. The homogenate was passed through four layers of cheese cloth and filtrate was centrifuged at $3000 \mathrm{rpm}$ for 5 min. Supernatant was used as enzyme source.
The substrate para nitro phenol phosphate of 1 $\mathrm{g}$ was dissolved in $100 \mathrm{ml}$ of water. One $\mathrm{ml}$ of substrate was pipetted out in to a test tube and $2 \mathrm{ml}$ enzyme extract and $5 \mathrm{ml}$ of $0.2 \mathrm{M}$ acetate buffer at $\mathrm{pH} 4.5$ were added. This mixture was incubated for $24 \mathrm{~h}$. One drop of 10 per cent trichloroacetic acid was added and centrifuged. One $\mathrm{ml}$ of supernatant was taken in a test tube and mixed with Folin- ciocalteu reagent and $2 \mathrm{ml}$ of 20 per cent sodium carbonate and boiled for one min at $100^{\circ} \mathrm{C}$. After cooling, the volume was made up to $10 \mathrm{ml}$ with distilled water. The colour intensity was read at 725 $\mathrm{nm}$ in Spectrophotometer. Standard curve using para nitro phenol was drawn and the activity was calculated at 30, 45 and 75 DAS and expressed as $\mu$ mole of para nitro phenol released g root tissue $\mathrm{e}^{-1} \mathrm{~h}^{-1}$.

\section{Alkaline phosphatase activity}

Alkaline phosphatase activity was measured by adopting the procedure described for acid phosphatase but using borate buffer $(0.2 \mathrm{M})$. Enzyme activity was calculated at 30, 45 and 75 DAS and expressed as $\mu$ mole of para nitro phenol released $g$ root tissue $\mathrm{e}^{-1}$.

\section{Results and Discussion}

Arbuscular mycorrhizal fungi colonization percentage was observed in the roots of green gram at different stages and it was found to be higher in T5 and T4 followed by T1. Soil samples were analyzed for spore count (Table 1). The treatments inoculated with AM fungi recorded higher colonization percentage and spore count than other treatments. Murat et al. (2011) reported that AMF inoculation with rhizobium inoculation, increased the root colonization. Mycorrhizal infection has particular value for legumes because nodulation and symbiotic nitrogen fixation by rhizobia require an adequate phosphorus supply and restricted root system leads to 
poor competition for soil phosphorus (Carling et al., 1978). In many of the legumes association of AM fungi and Rhizobium was noticed and called as tripartite association ship that strongly enhanced the growth and multiplication of Rhizobium and AM fungi (Silveira and Cardoso, 2004). Moreover the dual inoculation gives better results than individual application (Chalk et al., 2006). Even the consortium of biofertilzers like AM fungi, Rhizobium, PGPR and Phosphobacteria greatly improved the production of green gram and chick pea. (Ray and Valsalakumar, 2009)

Plant biometric observations revealed that plant height was higher in $\mathrm{T} 5$ followed by $\mathrm{T} 4$. The treatment that received AM fungi and Rhizobium performed better than other treatments.(Table 2). This results were in line with the findings of Jarande et al (2006) who noted the same like increase in growth parameters such as plant height, nodules etc. Murat et al. (2011) also reported that AM fungi inoculation, enhanced the yield, root colonization and phosphorus content of the seed and shoot. Likewise, Khan et al. (2008) found that the dry weight of shoot and root improved because of the dual inoculation of rhizobium and AM fungi. Bhattacharjee and Sharma (2012) also reported that dual inoculation has the capability to increase the number of nodules and also increase the nutrients content of pigeon pea. Similar research conducted by Kadam (2011) reported that improved growth and nodulation was observed because of the inoculation of symbiotic partners.

Acid and alkaline phosphatase activity was calculated in the root and shoot samples of green gram and the treatments $\mathrm{T} 5, \mathrm{~T} 4$ was found to be higher followed by T1 (Table 3). Enzyme activity was higher in root samples than in shoot samples. This has been linked with the reports of Mouradi et al., (2008) who stated increased acid phosphatase activity in the roots in drought condition. Several researchers have stated higher phosphatase activity in mycorrhizal inoculated plants than uninoculated control (Saito, 1995). In the present study also significant and higher phosphatase activity was reported and it may be due to the intense phosphatase activity of the internal hyphae of AM fungi that resulted in higher root ATPase activity (Kuiper et al., 1991). Control plants exhibited decreased phosphatase activity when compared to treatments. Same results were observed by Gantt et al., (1992) who also noted the same that of reduced phosphatase activity.

Table.1 Per cent colonization and Spore count (100 g $\mathrm{g}^{-1}$ of soil) of green gram

\begin{tabular}{|l|c|c|c|c|c|c|}
\hline \multirow{2}{*}{ Treatments } & \multicolumn{3}{|c|}{ Per cent colonization } & \multicolumn{3}{c|}{ Spore count } \\
\cline { 2 - 8 } & 30 DAS & 45 DAS & 60 DAS & 30 DAS & 45 DAS & 60 DAS \\
\hline T1 & 20 & 29 & 37 & 48 & 53 & 57 \\
\hline T2 & 9 & 12 & 15 & 15 & 20 & 29 \\
\hline T3 & 6 & 10 & 18 & 18 & 21 & 25 \\
\hline T4 & 25 & 28 & 39 & 70 & 74 & 82 \\
\hline T5 & 28 & 45 & 57 & 75 & 89 & 93 \\
\hline T6 & 4 & 9 & 11 & 8 & 17 & 23 \\
\hline SEd & 0.34 & 0.54 & 0.54 & 1.18 & 0.74 & 0.54 \\
CD $(\mathbf{0 . 0 5})$ & 074 & 1.18 & 1.18 & 2.58 & 1.61 & 1.18 \\
\hline
\end{tabular}


Table.2 Plant biometric observations in green gram inoculated with AM fungi and Rhizobium

\begin{tabular}{|c|c|c|c|c|c|c|c|c|}
\hline \multirow{2}{*}{ S.No. } & \multicolumn{2}{|c|}{$\begin{array}{c}\text { Shoot Length } \\
\text { (cm) }\end{array}$} & \multicolumn{2}{c|}{$\begin{array}{c}\text { Root Length } \\
(\mathbf{c m})\end{array}$} & \multicolumn{2}{c|}{ Plant Height (cm) } & \multicolumn{2}{c|}{$\begin{array}{c}\text { No of Nodules } \\
\text { /plant }\end{array}$} \\
\cline { 2 - 9 } & $\mathbf{3 0}$ & $\mathbf{4 5}$ & $\mathbf{3 0}$ & $\mathbf{4 5}$ & $\mathbf{3 0}$ DAS & 45 DAS & 30 DAS & 60 DAS \\
& DAS & DAS & DAS & DAS & & & & \\
\hline T1 & 17 & 28 & 7.5 & 15.5 & 24.5 & 43.5 & 7.0 & 9.0 \\
\hline T2 & 15 & 26 & 6.5 & 14 & 21.5 & 40 & 8.0 & 9.0 \\
\hline T3 & 16 & 27.5 & 7 & 15 & 23 & 42.5 & 8.7 & 9.3 \\
\hline T4 & 17.5 & 29 & 8.5 & 17 & 26 & 46 & 10.3 & 12.0 \\
\hline T5 & 20.5 & 30.5 & 8.5 & 18 & 29 & 48.5 & 12.0 & 15.0 \\
\hline T6 & 13.0 & 20.0 & 6.0 & 11.5 & 19.0 & 31.5 & 4.0 & 5.0 \\
\hline SEd & 0.39 & 0.62 & 0.10 & 0.23 & 0.32 & 1.00 & 0.20 & 0.19 \\
CD & 0.88 & 1.39 & 0.24 & 0.51 & 0.72 & 2.23 & 0.45 & 0.43 \\
$\mathbf{( 0 . 0 5 )}$ & & & & & & & & \\
\hline
\end{tabular}

Table.3 Acid and alkaline phosphatase activity in green gram

\begin{tabular}{|l|c|c|c|c|}
\hline \multirow{2}{*}{ Treatments } & \multicolumn{2}{|c|}{$\begin{array}{c}\text { Acid phosphatase (ug PNP/g / } \\
\text { min) }\end{array}$} & \multicolumn{2}{|c|}{$\begin{array}{c}\text { Alkaline phosphatase activity (ug } \\
\text { PNP / g / min) }\end{array}$} \\
\cline { 2 - 5 } & Root & Shoot & Root & Shoot \\
\hline T1 & 1.25 & 0.72 & 1.86 & 1.02 \\
\hline T2 & 1.15 & 0.55 & 1.70 & 0.84 \\
\hline T3 & 0.95 & 0.65 & 1.75 & 0.89 \\
\hline T4 & 1.38 & 0.81 & 2.05 & 1.19 \\
\hline T5 & 1.55 & 0.95 & 2.25 & 1.27 \\
\hline T6 & 0.75 & 0.40 & 1.25 & 0.64 \\
\hline SEd & 0.02 & 0.01 & 0.03 & 0.02 \\
CD $(\mathbf{0 . 0 5})$ & 0.05 & 0.02 & 0.07 & 0.05 \\
\hline
\end{tabular}

In a nutshell the dual inoculation of Rhizobium and AM fungi greatly influenced the growth and yield of green gram and this tripartite association ship also improved the quality traits of the grains. The results of the research was also in line with the reports of Yadav and Ashok, (2015) who also stated the tripartite relationship enhanced the yield and quality characteristics like protein and oil content of ground nut.

\section{References}

Arumugam, Rajasekaran \& Rajasekaran, S \& Nagarajan, SM. (2011). Response of Arbuscular mycorrhizal fungi and
Rhizobium inoculation on growth and chlorophyll content of Vigna unguiculata (L) Walp Var. Pusa 151. Journal of Applied Sciences and Environmental Management. 14.

Athar, Mohammad. 2005. Nodulation of Native Legumes in Pakistani Rangelands. Agriculturae Conspectus Scientificus (ACS). 70.

Carling, D. E., N. E. Richle, and D. R. Johnson. 1978. Effect of VAM on nitrate reductase and nitrogenase activity in nodulation and nonnodulating soybean. Phytopathology 68: 1590-1596.

Chalk, P. \& Souza, Renato \& Urquiaga, 
Segundo \& Alves, Bruno \& Boddey, Robert. (2006). The role of arbuscular mycorrhiza in legume symbiotic performance. Soil Biology and Biochemistry. 38. 2944-2951.

Gantt JS, Larson RJ, Farnham MW, Pathirana SM, Miller SS, Vance CP. 1992. Aspartate amino-transferase in effective and ineffective alfalfa nodules. Plant Physiology 98, 868-78

Harley JL, Harley EL 1987. A check-list of mycorrhiza in the British flora. New Phytol 105:1-102

Jarande, N.N., P.S. Mankar, V.S. Khawale, A.A. Kanase and J.T. Mendhe. 2006. Response of chickpea (Cicer arietinum L.) to different levels of phosphorus through inorganic and organic sources. J. Soils and Crops, 16(1): 240-243.

Mouradi, M., Farissi, M., Bouizgaren, A., Qaddoury, A., and Ghoulam, C. 2018 . Medicago sativa-rhizobia symbiosis under water deficit: physiological, antioxidant and nutritional responses in nodules and leaves. J. Plant Nutr. 41, 384-395.

Murat, E., S. Demir, E.O.S. Tufenkci, F. Oguz and A. Akkopru. 2011. Effects of Rhizobium, arbuscula rmycorrhiza and whey applications on some properties inchickpea (Cicer arietinum L.) under irrigated and rainfed conditions. Field Crops Res., 122(1): 14-24
Rajasekaran, S., and S. M. Nagarajan. 2005. Effect of dual inoculation (AM fungi and Rhizobium) on chlorophyll content of Vigna unguiculata (L) Walp. Var. Pusa 151. Mycorrhiza News 17: 10- 11.

Ray, J. G., and Valsalakumar, N. (2010). Arbuscular Mycorrhizal fungi and Piriformospora indica individually and in combination with Rhizobium on green gram. J. Plant nutr., 33(2): 285 298.

Saito M. 1995. Enzyme activities of the internal hyphae and germinated spores of an arbuscular mycorrhizal fungus, Gigaspora margarita Becker \& Hall. New Phytologist 129, 425-31.

Silveira, APD \& Cardoso, Elke. (2004). Arbuscular mycorrhiza and kinetic parameters of phosphorus absorption by bean plants. Scientia Agricola. 61. 203209.

Yadav, A and A. Ashok. 2015. The associative effect of arbuscularmycorrhizae with Trichoderma viride and Pseudomonas fluorescensin promoting growth, nutrient uptake and yield of Arachishy pogaea L. New York Science Journal, 8(1): 35-41.

Yoshihiro Kobae 2019. Dynamic Phosphate Uptake in Arbuscular Mycorrhizal Roots Under Field Conditions. Front. Environ. Sci., 09.

\section{How to cite this article:}

Gomathy, M., L. Srimathi Priya, K.G. Sabarinathan and Kumuda, K. 2021. Enhancing the Growth and Yield of Green Gram through Efficient Inoculation of AM Fungi and Rhizobium. Int.J.Curr.Microbiol.App.Sci. 10(01): 2315-2320. doi: https://doi.org/10.20546/ijcmas.2021.1001.268 